\title{
Short-rotation woody crops for bioenergy and biofuels applications
}

\author{
Maud Hinchee • William Rottmann • Lauren Mullinax • \\ Chunsheng Zhang • Shujun Chang • \\ Michael Cunningham • Leslie Pearson • Narender Nehra
}

Received: 12 April 2009 / Accepted: 24 July 2009 /Published online: 26 August 2009 / Editor: P. Lakshmanan

(C) The Author(s) 2009. This article is published with open access at Springerlink.com

\begin{abstract}
Purpose-grown trees will be part of the bioenergy solution in the United States, especially in the Southeast where plantation forestry is prevalent and economically important. Trees provide a "living biomass inventory" with existing end-use markets and associated infrastructure, unlike other biomass species such as perennial grasses. The economic feasibility of utilizing tree biomass is improved by increasing productivity through alternative silvicultural systems, improved breeding and biotechnology. Traditional breeding and selection, as well as the introduction of genes for improved growth and stress tolerance, have enabled high growth rates and improved site adaptability in trees grown for industrial applications. An example is the biotechnology-aided improvement of a highly productive tropical Eucalyptus hybrid, Eucalyptus grandis $\times$ Eucalyptus urophylla. This tree has acquired freeze tolerance by the introduction of a plant transcription factor that up-regulates the cold-response pathways and makes possible commercial plantings in the Southeastern United States. Transgenic trees with reduced lignin, modified lignin, or increased cellulose and hemicellulose will improve the efficiency of feedstock conversion into biofuels. Reduced lignin trees have been shown to improve efficiency in the pre-treatment step utilized in fermentation systems for biofuels production from lignocellulosics. For systems in which thermochemical or gasification approaches are utilized, increased density will be an important trait, while increased lignin might
\end{abstract}

M. Hinchee $(\triangle) \cdot$ W. Rottmann $\cdot$ L. Mullinax $\cdot$ C. Zhang $\cdot$

S. Chang $\cdot$ M. Cunningham $\cdot$ L. Pearson $\cdot$ N. Nehra

ArborGen, LLC, P.O. Box 840001, Summerville,

SC 29484, USA

e-mail: mahinch@arborgen.com be a desired trait for direct firing or co-firing of wood for energy. Trees developed through biotechnology, like all transgenic plants, need to go through the regulatory process, which involves biosafety and risk assessment analyses prior to commercialization.

Keywords Bioenergy · Biofuels · Biomass · Biotechnology Eucalyptus · Flowering control · Lignin modification .

Purpose-grown trees · Populus . Pine · Pinus · Productivity . Silviculture

\section{Introduction}

Woody biomass represents a renewable resource with multiple industrial applications. It serves as feedstock for the pulp and paper industry but also can be planted specifically to address the feedstock needs for the energy or biofuels industry. Trees and wood have been identified as part of the bioenergy solution in the "Billion Ton Report" (Perlack et al. 2005). This report investigated the feasibility of producing the estimated 1 billion dry tons of lignocellulosic biomass needed annually to meet the “' $30 \times 130$ " goal for a $30 \%$ replacement of United States petroleum consumption with biofuels by 2030. In this report, trees grown for bioenergy applications were included under the heading of agricultural resources as part of the broadly defined "perennial energy crops". Purpose-grown trees are expected to account for 377 million dry tons of the 1.37 billion dry ton total biomass resource potential at projected yields of 8 dry tons/acre/yr (Perlack et al. 2005).

It is expected that short-rotation woody crops, such as fast growing species Populus, Salix, and Eucalyptus and their respective hybrids, will be planted as purpose-grown 
wood on sites that enable high productivity and proximity to the processing plant. Short-rotation, purpose-grown trees have a variety of inherent logistical benefits and economic advantages relative to other lignocellulosic energy crops. Many of these advantages are driven by the fact that trees can typically be harvested year-round and continue growing year after year providing a "living inventory" of available biomass. Due to the flexibility associated with harvest time, trees have reduced storage and inventory holding costs and can minimize shrinkage or degradation losses typically associated with storage of annually-harvested biomass. Since trees can be harvested after several years and at different times, tree biomass mitigates the risk of annual yield fluctuations due to drought, disease and pest pressures, as well as other biotic or abiotic stresses. This allows a better matching of biomass supply with demand. An excess supply of an annually-harvested crop is necessary to hedge against years in which low yields are experienced in order to ensure full capacity utilization at a processing plant. Year-round harvest of trees enables the harvest and transport of wood to be distributed throughout the year, reducing infrastructure needs relative to annually-harvest crops (Sims and Venturi 2004).

Purpose-grown trees would minimize environmental impacts associated with biomass production since multiyear rotations of trees allow for extended periods between harvests with limited disturbance to the land. The multi-year rotation of trees also offers deployment and logistical benefits by reducing the land footprint that must be planted and harvested each year. While the acreage to feed a bioenergy plant may be similar between trees and other bioenergy crops with similar productivity, only a fraction of that total footprint would need to be planted or harvested in any given year for trees (Table 1). Purpose-grown trees for biomass also provide feedstock growers greater economic flexibility relative to other energy crops. The grower is provided a choice in harvest time as well as multiple end uses: traditional forest products and energy products such as cellulosic ethanol and power generation through direct firing, co-firing, or wood pellet systems.

\section{Current Limitations to the Use of Woody Feedstock for Biofuel Production}

It has been projected by the U.S. Department of Energy and others that a productivity rate of 8 to 10 dry tons/acre/yr will be required for the long-term feasibility of renewable energy production (English et al. 2006). Research has been conducted on growing short-rotation trees for bioenergy in the United States and other countries (Short Rotation Forestry Handbook 1995). Short-rotation coppicing of hardwoods offers the promise to produce biomass for bioenergy. Coppicing is the process by which new shoots and trees are regenerated from a cut stump following harvest. The use of coppiced hardwoods for this purpose is not novel, although it is the subject of renewed interest and focused research (Andersson et al. 2002; Dickmann 2006). There are currently 12,000 acres of intensively managed short-rotation hardwoods. There are two main silvicultural systems: (1) moderately dense stands of cottonwood, and (2) dense stands with 1- to 4-yr rotations usually using willows (Salix species) or sycamore (Plantanus occidentalis). Loblolly pine (Pinus taeda) and sweetgum (Liquidambar styraciflua) plantations are also being considered for bioenergy applications (Davis and Trettin 2006; Dickmann 2006). However, the typical biomass productivity for these species is most likely not cost effectively adequate to meet the demand. For example, short-rotation willow crop yields range from 3 to 7 oven-dry tons/acre/yr (Mead 2005). Sweetgum and sycamore plantations grown for $7 \mathrm{yr}$ on old agricultural land had, respectively, productivities of 1 and 2.3 oven-dry tons/yr, although this is expected to increase later in the rotation (Davis and Trettin 2006). Populus deltoides (eastern cottonwood) planted on good sites can produce an average yield of 5 dry tons/acre/yr. Loblolly pine grown to a 20 -yr rotation can produce an average 4 dry tons/acre/yr (Mercker 2007).

It is clear that to achieve the productivity gains required for tree biofuel and bioenergy applications, a significant research effort is needed for improving tree genetics and silvicultural practices. The economics of a purpose-grown tree feedstock for energy may not be feasible unless there is significant genetic improvement in the base growth rate. There are two basic biotechnological strategies to achieve

Table 1. Total and annual acreage needs for trees relative to annually-harvested energy crops, data (generated from an ArborGen financial model by L. Mullinax)

\begin{tabular}{|c|c|c|c|c|c|}
\hline Feedstock & $\begin{array}{l}\text { Biomass needed } \\
\text { (MM green tons/year) }\end{array}$ & $\begin{array}{l}\text { Productivity } \\
\text { (green tons/acre/year) }\end{array}$ & $\begin{array}{l}\text { Rotation length } \\
\text { (years) }\end{array}$ & $\begin{array}{l}\text { Total acres } \\
\text { needed (MM) }\end{array}$ & $\begin{array}{l}\text { Acres planted } \\
\text { annually (MM) }\end{array}$ \\
\hline Trees & 100 & 20 & 6 & 5 & 0.83 \\
\hline Annually-harvested crop & 100 & 20 & 1 & 5 & 5 \\
\hline
\end{tabular}


dramatic improvements in growth in plantation trees. The first is to genetically improve productivity of indigenous trees. The second strategy is to genetically improve the adaptability of exceptionally productive introduced trees so they can grow in the United States.

\section{Genetics, Silviculture, and Biotechnology Enable Short-Rotation Trees}

Productivity improvements, such as provided through advanced planting stock, optimal siliviculture and biotech traits, will be important for the cost-effective deployment of short-rotation trees for biomass applications. The improvement mechanism will be dependent on the biological and genetic limitations of the species utilized, in addition to the climate, soil, and moisture conditions of the tree plantation. Both native and exotic tree species can be considered potential feedstock sources. The approaches for successful short-rotation forestry for both native and exotic trees will be discussed.

\section{Increased Biomass Productivity through Genetic Improvement of Native Species}

Populus. Various Populus species and their hybrids are among the most rapidly growing trees adapted to temperate climates. However, the high inherent growth potential of trees in this genus is often manifested only at the most favorable sites. The challenge is to determine if specific Populus genotypes can demonstrate wide adapatability across a range of sites and environmental conditions. Unless strategies to increase productivity are employed together with tolerance to abiotic and biotic stresses, plantations of Populus species and hybrids will remain limited.

Several strategies offer potential to overcome these limitations and allow Populus to play an increasingly important role in bioenergy initiatives. The first and most straightforward of these strategies is through traditional breeding to generate hybrids and varieties that grow fast, have high volume increments, and can grow across a wide range of sites. For example, advanced Populus clones are being developed by companies such as ArborGen, LLC and Greenwood Resources (http://www.greenwoodresources. com) to have greater productivity and adaptability. These programs typically consist of breeding among selected genotypes within a species or between species and then testing the seedling progeny in a series of field trials. The first tests are in a nursery at close spacing to evaluate the genotypes for broad adaptability and resistance to various pests; this is followed by one or more series of vegetatively propagated field trials in which the varieties are further screened for suitability to diverse planting sites. Commercial candidates are typically selected based on projected yields and wood properties after as many as $10 \mathrm{yr}$ of field testing.

In addition, the Oak Ridge National Laboratory, in conjunction with the Bioenergy Feedstock Development Program and Boise Cascade Corp. is developing methods to identify drought-tolerant genotypes based on the presence of certain leaf metabolites (Oak Ridge National Laboratory, http://bioenergy.ornl.gov/papers/misc/drotpopl.html). These techniques could reduce the cost and improve the efficiency of breeding and selection of Populus varieties adapted to upland sites.

The second approach involves direct genetic modification to add or modify genes that increase growth, increase stress tolerance and improve adaptability. It has been suggested that suboptimal nutrient and water availability limit Populus adaptability and productivity on many sites. Genes and gene families have been identified that have the ability to alter plant responses to water and nutrient limitations (Tuskan et al. 2006). Introduced genes being tested in Populus include the Populus tremula and Arabidopsis stable protein 1 (SP-1) gene, as well as genes involved in metabolic processes responsive to drought, redox proteins, transporter proteins, signal transduction proteins, and transcription factors (Polle et al. 2006).

A third approach would be to add genes to already widely adapted genotypes to improve their growth rate and productivity. Improved growth has been achieved in Populus through gene insertion technology. Kirby and coworkers at Rutgers University, who studied over-expression of a conifer cytosolic glutamine synthetase (GS1) in Populus (Fu et al. 2003; Man Hui-min et al. 2005), showed that greenhouse-grown GS1 transgenic trees had a greater than $100 \%$ increase in leaf biomass relative to controls when grown under low nitrogen conditions (Man Hui-min et al. 2005). The effect was less marked when more nitrogen was available. Glutamine synthetase (GS), found in either cytosolic or plastid located isoforms, is responsible for $\mathrm{NH}_{4}^{+}$assimilation in an ATP-requiring reaction that produces the amino acid glutamine from glutamic acid (reviewed in Good et al. 2004). The effect of the transgene was confirmed by measurement of increased glutamine synthetase enzyme activity, along with decreased foliar $\mathrm{NH}_{4}{ }^{+}$and increased amino acids. Transgenic Populus characterized by over-expression of pine cytosolic glutamine synthetase gene exhibits other beneficial phenotypes including enhanced tolerance to water stress (El-Khatib et al. 2004) and enhanced nitrogen use efficiency (Man Hui-min et al. 2005).

Another enzyme in nitrogen assimilation is Fdx-GOGAT, which is predominant in leaves and believed to act to recycle 
$\mathrm{NH}_{4}^{+}$released in photorespiration. NADH-GOGAT is expressed more in roots and cotyledons, so it is believed to recycle $\mathrm{NH}_{4}^{+}$from catabolism of amino acids, including senescence. A strategy of over-expressing Fdx-GOGAT using a strong constitutive promoter should increase $\mathrm{NH}_{4}{ }^{+}$ recycling. When NADH-GOGAT was over-expressed in tobacco tissues, there was a $30 \%$ increase in foliar biomass but the nitrogen to carbon ratio remained unchanged (Chichkova et al. 2001). It is not known whether the level of GS becomes limiting in these transgenic plants, but it is conceivable that a stacked GS plus GOGAT construct would further improve nitrogen utilization further.

Genes involved in cell wall development have also been shown to affect tree growth. A $\beta-1,4-$ endoglucanase (cel1) involved in cell wall modification during cell growth has improved growth in Populus (Shani et al. 2004). Genes involved in leaf size and structure, stem development, timing of bud flush and leaf senescence all may influence biomass accumulation, rotation time and growth rate. For example, it has been shown that a gibberellin catabolism gene, GA 2-oxidase can affect tree height (Busov et al. 2003). It is also possible that genes that confer stress tolerance or delay senescence could also improve growth under environmental stress conditions or could extend the growing season, and it has been shown that suppression of a gene, deoxyhypusine synthase (DHS) which is part of the stress-response pathway, increases vegetative and reproductive growth in the model plant Arabidopsis (Duguay et al. 2007).

Pinus. Loblolly pine, as a native North American species, has the advantage of wide adapatability across sites at less than 2,000 $\mathrm{ft}$ in elevation. Currently, it is the most widely planted forestry species in the world, with an average 900 million seedlings planted annually in the southeastern United States alone (McKeand et al. 2003). Its wood, because of its lignin chemistry, is currently best suited for bioenergy applications that utilize direct firing or gasification technologies, although scientists believe that enzymatic processes might also be utilized in the future (Frederick et al. 2008). However, the economic limitation for loblolly pine in biofuel and bioenergy applications is its relatively long rotation time ( $15 \mathrm{yr}$ for pulp wood applications and $23 \mathrm{yr}$ for sawtimber applications).

To address this limitation, ArborGen and other treebreeding organizations are employing advanced breeding and crossing methods to develop high-performing traditional seedlings that have improved growth, disease resistance, and form. ArborGen and two other companies (CellFor and Weyerhaeuser) have also utilized a tissue culture process called somatic embryogenesis to masspropagate selected elite loblolly genotypes. Improvements in traditional breeding and selection are predicted to achieve $35 \%$ volume gains and sawtimber rotation times of approximately $20 \mathrm{yr}$. Biotech gene insertion methods will be necessary to develop loblolly pine with the productivity levels most desirable for bioenergy applications. Early research results indicate that rotation times of $15 \mathrm{yr}$ may be possible. ArborGen has introduced genes into loblolly pine that demonstrated nearly double the normal biomass production in the first $3 \mathrm{yr}$ of field trials (unpublished results).

\section{Increased Biomass Productivity through Genetic Improvement of Introduced Species}

Eucalyptus is an ideal energy crop with certain species and hybrids having excellent biomass productivity, relatively low lignin content and a short rotation time. In Brazil, commonly planted Eucalyptus hybrids such as Eucalyptus grandis $\times$ Eucalyptus urophylla, routinely yield 10-12 dry tons/acre/yr. A study with $E$. grandis in Florida indicated that this species could achieve total biomass productivity values exceeding 30 green tons ( $\sim 15$ dry tons) /acre/yr, with the potential to reach 55 green tons/acre/yr (Stricker et al. 2000). This scale of productivity addresses the biomass requirements for cost-effective generation of biofuels and bioenergy from lignocellulosic feedstocks. Eucalyptus species and hybrids with this level of productivity are adapted to growth in the tropics and are highly sensitive to freezing temperatures.

Through a significant advance in the understanding of freezing tolerance in Arabidopsis, a freeze-tolerant Eucalyptus has been developed. This advance was the discovery of the C-repeat/dehydration-responsive element binding factor $(C B F / D R E B)$ cold-response pathway (Jaglo-Ottosen et al. 1998; Liu et al. 1998). The functions of Arabidopsis $\mathrm{CBF}$ genes and CBF homologs identified in many species of plants have been studied extensively using transgenic plants. Over-expression of $C B F$ genes conferred freezing tolerance and drought tolerance, as well as salt tolerance in Arabidopsis (Liu et al. 1998; Kasuga et al. 1999). Overexpression of Arabidopsis CBF genes in Brassica napus and tobacco induced the expression of orthologs of Arabidopsis $C B F$-targeted genes and increased freezing and drought tolerance of transgenic plants (Jaglo-Ottosen et al. 2001; Kasuga et al. 2004). Heterologous expression of Arabidopsis $C B F 1$ resulted in enhanced chilling tolerance but not freezing tolerance in transgenic tomato (Hsieh et al. 2002; Zhang et al. 2004). Over-expression of a $C B F$ homolog obtained from pepper, $C a P F 1$, in tobacco and Arabidopsis improved freezing tolerance of the transgenic plants (Yi et al. 2004). Ectopic expression of Arabidopsis $C B F 1$ in Populus increased freezing tolerance of the 
transgenic Populus (Benedict et al. 2006). In rice, four $C B F$ homologs have been identified, and over-expression of one of the homologs (OsDREB1A) in Arabidopsis conferred enhanced freezing tolerance and high-salinity tolerance (Dubouzet et al. 2003; Ito et al. 2006). A CBF homolog, $Z m D R E B 1 A$, was found in maize, and over-expression of this gene in Arabidopsis resulted in improved freezing and drought tolerance (Qin et al. 2004). Several CBF homologs were identified in wheat, and it was found that these genes clustered in a chromosome locus. It has been shown that this locus mediated Cor/Lea gene expression and freezing tolerance in common wheat (Jaglo-Ottosen et al. 2001; Kobayashi et al. 2005; Vagujfalvi et al. 2005). All of the above research strongly suggests that $\mathrm{CBF}$ genes are playing an important role in stress tolerance, especially the freezing tolerance, in plants.

The $C B F 2$ gene is part of the C-repeat/dehydrationresponsive element binding factor $(C B F / D R E B)$ coldresponse pathway (Jaglo-Ottosen et al. 1998; Zhang et al. 2004). It is known from the literature that over-expression of $\mathrm{CBF}$ genes under control of a constitutive promoter can increase cold tolerance but can also promote dwarfing (Zhang et al. 2004). To overcome this problem, stressinducible plant promoters with a low background expression level have been used in conjunction with the cold tolerance genes (Yamaguchi-Shinozaki and Shinozaki 1994).

ArborGen has introduced the Arabidopsis CBF2 transcription factor driven by the Arabidopsis rd29a stressinducible promoter (Yamaguchi-Shinozaki and Shinozaki 1993) into a highly productive tropical Eucalyptus E. grandis $\times E$. urophylla genotype. The new variety, Freeze-tolerant Eucalyptus, has demonstrated tolerance to $16^{\circ} \mathrm{F}$ across multiple years and multiple field trial locations while essentially maintaining its exceptional productivity (ArborGen unpublished data; Fig. 1).

The yields achievable with Freeze-tolerant Eucalyptus are predicted to meet or exceed those that have been defined by DOE and others for the long-term-feasibility of renewable energy production (i.e., 8 to 10 dry tons/acre/yr; English et al. 2006). The application of total biomassdriven management systems could further increase yields and reduce delivered costs. As with many other hardwood species, an added benefit of Freeze-tolerant Eucalyptus is its ability to coppice when managed appropriately. Coppicing allows for subsequent crops without the added costs of establishment (site preparation, seedling, and planting costs), which can provide a higher return to landowners. Coppice crops can show increases in productivity relative to the initial single-stem harvest (Sims 2001), but coppice yields will decline over time. Re-planting will then become economically attractive as new varieties become available.
Improvements like those discussed above will be necessary to make forest trees a sustainable and economical feedstock option for the production of cellulosic ethanol and other forms of bioenergy. Table 2 summarizes the theoretical acreage needed to meet the "advanced biofuels" target in the 2007 Renewable Fuel Standard (RFS) in the southeastern United States based on current productivity assumptions for loblolly pine and Eucalyptus under pulpwood and high-density coppicing scenarios.

\section{Altering Wood Quality to Improve Feedstock Conversion Efficiency}

Once woody biomass can be grown productively with a cost-effective delivered cost at the conversion plant, improvements in the wood itself will have great value for biofuels or bioenergy conversion. If wood is used as a feedstock for ethanol production, there are two general target areas for modifying the wood to increase ethanol yield per ton of wood. Foremost, the polysaccharides should be made more easily degradable and accessible to the enzymes and/or microorganisms used to break them down. Another avenue is to reduce the concentrations of compounds that inhibit the fermentation of the sugars once they are released. These factors contribute to the "recalcitrance" of cellulosic feedstocks to saccharification relative to sucrose and starch. The DOE has funded several bioenergy science centers to address biological and technological barriers to cost-effective production of biofuels from lignocellusic feedstocks. One such center, the BioEnergy Science Center managed by Oak Ridge National Laboratory, has focused its research on the reducing factors that contribute to the recalcitrance of wood in biofuels conversion (see http://genomicsgtl.energy.gov/centers/ center_ORNL.shtml).

One approach that addresses both areas outlined above would be to reduce the lignin content of the wood or at least make it easier to remove. Reduction of lignin has long been a target of interest in crop and forestry species, because lignin interferes with digestion of plant materials by farm animals and removal of lignin is a costly step in the production of paper. This has motivated researchers to identify and isolate from a variety of species many of the genes coding for enzymes in the lignin pathway. A large body of research involving manipulation of the lignin biosynthetic pathway in transgenic plants has accumulated over the past $15 \mathrm{yr}$; this has been exhaustively reviewed (Anterola and Lewis 2002; Boerjan et al. 2003; Li et al. 2008; Vanholme et al. 2008; Weng et al. 2008). In broad strokes, experiments have shown that lignin content can be significantly reduced in trees and herbaceous plants. For example, several of the transgenic plants with down- 

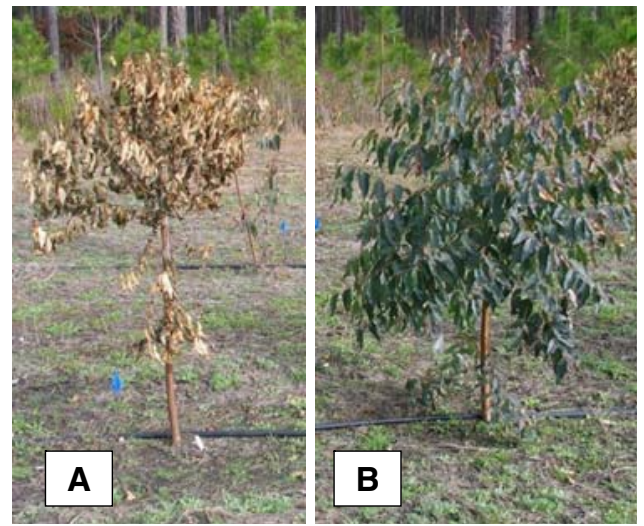

Figure 1. A Eucalyptus hybrid, with or without the addition of a freeze tolerance gene, after a typical winter in the Southeast United States. (a) photograph of control Eucalyptus after winter temperatures of $16^{\circ} \mathrm{F}$ in South Carolina, (b): rd29a::CBF2 transgenic EH1, photograph taken from the same field trial and time as the tree in

regulated genes for lignin biosynthetic enzymes in the early steps of the pathway showed that syringyl lignin (S-lignin) content was more strongly affected than guaiacyl lignin (G-lignin) content (Vanholme et al. 2008).

Optimal reduction of lignin with negligible negative effects will require use of carefully selected promoters and target genes, as lignin reduction is often seen with other associated effects. Examples of pleiotropic effects from lignin reduction in Populus are: (1) the accumulation of sugars in leaves and concomitant reduction of photosynthetic capacity following down-regulation of $p$-coumaroyl shikimate 3'-hydroxylase (Coleman et al. 2008) and (2) the reduction of hemicellulose that occurred with downregulation of cinnamoyl-coenzyme A reductase (Leplé et al. 2007). Increased cavitation and vessel collapse have also been observed in some plants with reduced lignin (Coleman et al. 2008). Another means of modifying lignin production that may address these negative pleiotropic effects is to alter the expression of transcription factors or other regulators

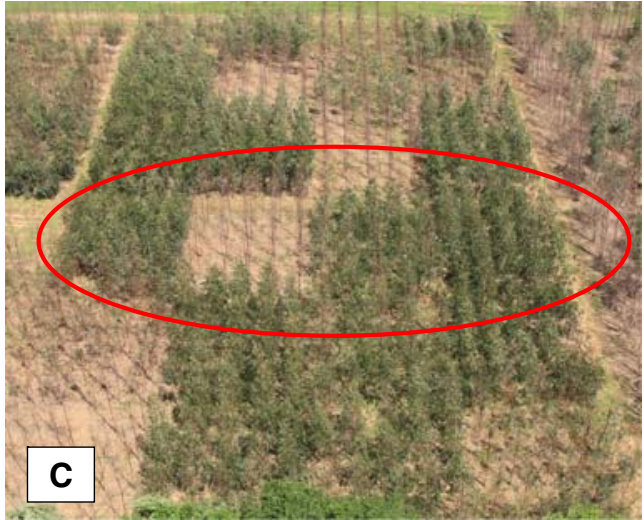

photograph (a). Photograph (c) an aerial photograph of block plots of different lines of rd29a::CBF2 Eucalyptus in a field trial in Alabama after winter temperatures of $19^{\circ} \mathrm{F}$. A control tree block is marked with a "**, and all other similar blocks are also control blocks.

which in turn modify the expression of a whole suite of genes that participate in the lignin biosynthesis pathway. Masaru Ohme-Takagi and colleagues showed that two plant-specific transcription factors, designated NAC secondary wall thickenings promoting factor 1 (NST1) and NST3, regulate the formation of secondary walls in woody tissues of Arabidopsis. (Mitsuda et al. 2007).

An increased syringyl lignin to guaiacyl lignin $(\mathrm{S} / \mathrm{G})$ ratio is thought to be desirable because the more oxygenrich S-lignin is easier to remove through chemical treatment during pulping (Chiang and Funaoka 1990). This can be achieved by over-expression of ferulate 5-hydroxylase $(\mathrm{F} 5 \mathrm{H})$, also known as coniferaldehyde 5-hydroxylase (Cald5H; Huntley et al. 2003). Interestingly, it has been reported that the composition of lignin does not have a strong effect on biological degradation of cell walls (Grabber et al. 1997).

The polysaccharides themselves contribute a large part to recalcitrance because of their insolubility. In both conifer

Table 2. Approximate productivity and total planted acreage needed to meet the Renewable Fuel Standard (RFS) in the southeastern United States using purpose-grown pine or Eucalyptus

\section{Pinus taeda Eucalyptus urograndis}

Pulpwood management Total biomass management

\begin{tabular}{llrr}
\hline Productivity (green tons/acre/yr) & $10^{\mathrm{z}}$ & $20^{\mathrm{y}}$ & $30^{\mathrm{x}}$ \\
Planted acres (million) needed to meet target 118 million green tons/yr ${ }^{\mathrm{a}}$ & 17 & 6 & 4
\end{tabular}

On December 19, 2007, the Energy Independence and Security Act of 2007 (H.R. 6) was signed into law. This comprehensive energy legislation amends the Renewable Fuel Standard (RFS) signed into law in 2005, growing to 36 billion gallons of biofuels available in 2022

${ }^{\mathrm{z}}$ ArborGen, unpublished data, assumes as 10-yr rotation with a planting density of 1,000 trees per acre

${ }^{y}$ ArborGen, unpublished data, assumes as 7-yr rotation, with 450 trees/acre

${ }^{\mathrm{x}}$ ArborGen unpublished data, assumes an average product of an initial harvest at $3 \mathrm{yr}$, followed by three coppice rotations of approximately 3 yr coppice rotation, using a similar coppicing regime as described in Sims 2001) 
and hardwood (angiosperm) secondary cell walls, cellulose is approximately $45 \%$ of the dry weight of the wood while hemicellulose is approximately $20 \%$. Hemicellulose composition varies strongly depending upon the wood source. In the hemicellulose of hardwoods such as Populus, xylans comprise about $80 \%$ with the remainder being mannans $(10 \%)$, galactans $(5 \%)$, and arabinans $(<5 \%)$. In pine, mannans comprise about $50 \%$, xylans $30 \%$, galactans $10 \%$, and arabinans $5 \%$ of the total hemicellulose. Although these composition percentages reflect data obtained by the authors in their own research, these closely match other published numbers for hardwoods and conifers (Rowell 2005).

If wood is to be used simply as a fuel for burning, the two obvious targets for modification are increasing density and increasing lignin content. Increasing wood density has the potential of increasing the yield of fuel per acre and decreasing transportation and storage costs (increasing the energy yield per truckload of wood or chips), although the amount of energy per unit weight of wood would remain the same. Production of biofuels via gasification would also benefit from these aspects of increased wood density. It seems unlikely that it would be possible to insert significantly more material into the cell wall matrix, but decreasing the ratio of lumen volume to cell wall volume is a plausible route to increasing wood density. The methods by which the lumen-to-wall ratio can be decreased are rather speculative because the molecular biology of xylem development is only beginning to be understood. Goicoechea et al. (2005) describes how strong expression of a Eucalyptus gunnii MYB transcription factor (EgMYB2) in tobacco led to significant thickening of xylem fiber cell walls. Because the transcription factor was first isolated based on its ability to bind the promoters of lignin biosynthetic genes, and these genes are up-regulated in the EgMYB2 over-expressing lines (Goicoechea et al. 2005), it is possible that the phenotype is due to an overall rate increase in deposition of the S2 layer of the secondary cell wall.

Increasing lignin content would increase the thermal energy of wood. Pure cellulose has a calorific value of $\sim 8,000 \mathrm{BTU} / \mathrm{lb}$; pure lignin is $\sim 11,000 \mathrm{BTU} / \mathrm{lb}$ (White 1987). Increasing lignin content from $25 \%$ to $35 \%$ would increase the calorific value of wood by approximately $450 \mathrm{BTU} / \mathrm{lb}$. This might be accomplished by achieving the opposite of the lignin reduction strategies mentioned above. The over-expression of an enzyme that is a kinetic barrier in the pathway is one possible approach, as is up-regulation of the whole set of biosynthetic genes with a regulatory protein. There have been several reports of increased lignin deposition due to overexpression of MYB transcription factors (Patzlaff et al. 2003; Goicoechea et al. 2005).
As the DOE has funded 3 collaborative centers for research focused on improving lignocellulosic feedstock and related downstream processes for improved conversion efficiency, it is anticipated that within the next $5 \mathrm{yr}$ much more will be known about genes that can be used to address the recalcitrance of plant cell walls to enzymatic biofuels conversion methods.

\section{Regulatory Requirements and Associated Risk Assessment for Biotech Trees}

It is likely that the use of woody feedstock for liquid biofuels production will require biotech traits in order to provide an economically feasible process. Currently, no biotech trees are planted for industrial forestry in the United States. Biotech trees for biofuels production will require regulatory oversight and de-regulation prior to being commercialized.

Domestication, breeding, and selection of plants, including forest tree species, has resulted in direct and indirect change in the genetic makeup of plants grown for food and industrial applications. Forest tree domestication accelerated during the latter half of the twentieth century with conventional breeding methods applied to forest tree populations to improve growth, volume, and wood quality traits (Burdon and Libby 2006). The application of biotechnology to forest tree species is expected to further accelerate such improvement (Sedjo 2001), including new developments for bioenergy applications. Commercialization of improved planting stocks, based on new varieties generated through clonal propagation and advanced breeding programs, as well as further improved biotech trees with high value traits, will occur in the near future. These trees will further enhance the quality and productivity of plantation forests (Nehra et al. 2005) and will provide a renewable resource for industrial applications.

In 1986, the United States developed the Coordinated Framework for Regulation of Biotechnology. A key aspect of the framework was the understanding that the characteristics, composition, and intended use of the genetically modified (GM) product were the important considerations in their regulation, not the methods by which they were developed. Under this framework, the United States Department of Agriculture, Animal and Plant Health Inspection Service (USDA-APHIS), Food and Drug Administration (FDA), and Environmental Protection Agency (EPA) coordinate the regulation of GM crops. The agencies' roles in assessing the safety and approval of GE products depend on the intended use of the product; for example, FDA oversees food and feed uses while EPA oversees insect pest management applications (Re et al. 1996; Nehra et al. 2005; Just et al. 2006). APHIS plays a 
major role in overseeing field testing, risk assessment and approval of genetically modified plants for planting. In 2002, APHIS created the Biotechnology Regulatory Services (BRS) unit that manages all activities with respect to risk assessment of genetically modified organisms, including tree species (www.aphis.usda.gov/brs/). Developers must obtain permits from BRS prior to any release into the environment in field trials. BRS conducts in-depth analyses as part of the permitting process for field trials and their assessment of petitions for non-regulated status. All genetically modified plants are considered as regulated articles by BRS, and prior to commercialization developers provide data from field trials and other analyses to BRS in the form of a petition requesting non-regulated status. APHIS-BRS oversight of genetically modified plants is provided by the Plant Protection Act of 2000. This Act gives them the authority to assess any potential noxious weed or plant pest risk. BRS' assessment also involves analyses in fulfillment of its obligations under the National Environmental Policy Act (NEPA) and Endangered Species Act. The US system for oversight and regulation of transgenic plants has worked effectively for more than $23 \mathrm{yr}$, ensuring the safety of biotech crops and protection of the environment. BRS is now considering a number of proposals for further improvement to make regulation more streamlined and proportional to product novelty and risk (http://federalregister.gov/).

Since the commercialization of the first biotech crops in 1996, the adoption rate of biotech crops has increased rapidly worldwide, with more than 2 billion acres planted in 25 countries (ISAAA 2008). Field tests of genetically modified trees are being conducted in several countries, with the majority of these field tests occurring in the US (van Frankenhuyzen and Beardmore 2004; http://www.isb. vt.edu/). To date, only two tree species, papaya and plum, have been granted non-regulated status for planting in the United States; these fruit trees are resistant to viruses that can have devastating impacts on fruit production and quality. There are currently no large-scale plantings of transgenic forest trees other than an insect resistant poplar that is being grown in China ( $\mathrm{Hu}$ et al. 2001). More recently, a petition was submitted to BRS requesting nonregulated status for the Freeze-tolerant Eucalyptus hybrid described above.

It is recognized that the use of biotechnology for tree improvement can bring significant economic, social and environmental benefits, but some concerns must also be addressed (van Frankenhuyzen and Beardmore 2004), particularly those associated with the potential dispersal of pollen, seeds or vegetative propagules. Gene flow via pollen and seed dispersal is an important natural phenomenon for genetic improvement and evolution in plant species. The potential for gene flow from crops, be they from traditional breeding or developed through biotechnology, is considered to be less for non-native self-pollinated crops compared to native and wind pollinated species. Perennial wind pollinated species models predict that a small proportion of pollen and seed can travel long distance (Nathan et al. 2002; Williams 2005; Williams and Davis 2005). However, for there to be any consequences of such dispersal these models assume that: (1) viable pollen is able to fertilize receptive ovules of a related species resulting in viable seed production, followed by establishment of this seed in the environment and (2) adverse consequences can occur only if the inserted genes are considered a significant risk to other organisms or can cause unintended effects on the fitness of the species. Traits including improved growth, wood quality, and abiotic or biotic stress tolerance that are also being altered via traditional breeding might be considered as being inherently low risk, particularly when using genes from the tree itself, or other plant genes that are homologous to genes already present in the tree, where no unintended phenotypes have been observed after extensive field testing. In some cases, especially for biomass
Figure 2. Bags containing male cone clusters of untransformed control and transgenic lines of $P$. taeda (ArborGen unpublished data). Yellow-colored pollen is clearly visible inside bags containing untransformed male cones (left), while no pollen was found inside the bags containing male cones of lines transformed with genes for pollen ablation (right).

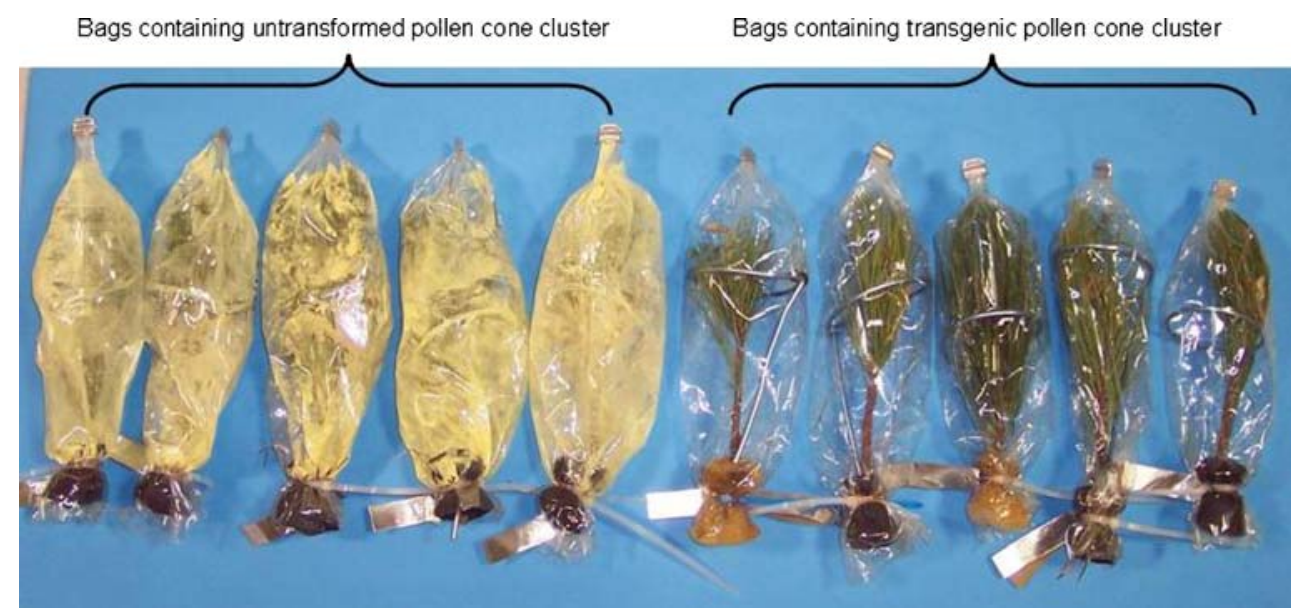


production for bioenergy uses, short-rotation trees may not even produce abundant pollen or seed prior to harvest. In addition, there are proven and well-tested technologies that selectively prevent or reduce pollen formation without affecting other functions of the plant species (Gomez Jimenez et al. 2006; Nasrallah et al. 1999; Yanofsky 2006). ArborGen has adapted this technology for use in tree species and demonstrated high levels of efficacy (Fig. 2). Therefore, a number of tools exist that can minimize the potential risk of gene flow via pollen or seed dispersal from plantations. It is important, however, that any risk assessments for trees take into account scientifically informed arguments for incorporating any such gene flow control mechanisms on a case-by-case basis.

\section{Conclusion}

The high productivity of purpose-grown, short-rotation trees, such as Freeze-tolerant Eucalyptus, is expected to improve the economic feasibility of bioenergy and biofuels production from woody biomass plantations. Bioenergy is already becoming a substantial market outlet for wood. According to TimberMart-South (2008), 16 new bioenergy projects were announced for the U.S. south within the last $2 \mathrm{yr}$, with an anticipated increase in wood consumption of 9 million green tons. The development of a bioenergy sector in the southeastern United States holds great economic promise, and it is anticipated that purpose-grown, shortrotation trees will be planted to address the 120 million green tons of biomass that will be needed annually as a feedstock for advanced biofuels and bioenergy. At an estimated price of $\$ 20$ to $\$ 30$ per green ton, this represents 2 to 4 billion dollars in economic opportunity associated with biomass production for the southeastern United States. Upside demand exists because of the suitability of wood for other bioenergy applications, such as the production of electricity through direct burning of wood or co-firing with coal.

The inherent logistical benefits of trees in combination with the high productivity of new varieties of short-rotation trees, such as Freeze-tolerant Eucalyptus, make it an ideal biomass for traditional industrial end uses such as pulp and paper, as well as for energy products such as cellulosic ethanol and electric power generation. Short-rotation trees will generate more wood on less land, requiring a smaller plantation footprint to generate the necessary dry tons to feed industrial processing plants. This, in turn, will lessen pressure to harvest from native and old-growth forests in order to meet society's demand for pulp, paper and energy. The addition of biotech traits to elite varieties of purpose-grown trees will achieve the required rotation times and productivity to make lignocellulosic feedstocks cost effective.
The choice of which energy crops to plant must take into consideration regional conditions and needs, both in minimizing transportation costs as well as in avoiding the current long-distance distribution limitations of ethanol. In the southeastern United States, where accessible inventory and harvesting infrastructure for forestry operations are already well established, trees provide a clear advantage for biomass production compared to annual crops. Although trees will play a significant role in helping to meet renewable energy standards, it is recognized that multiple, integrated approaches with a variety of different crop species and production systems will be required to meet our total renewable energy objectives.

Open Access This article is distributed under the terms of the Creative Commons Attribution Noncommercial License which permits any noncommercial use, distribution, and reproduction in any medium, provided the original author(s) and source are credited.

\section{References}

Andersson G.; Asikainen A.; Bjorheden R.; Hall P. W.; Hudson J. B.; Jirjis R.; Mead D. J.; Nurmi J.; Weetman G. F. Production of forest energy. In: Richardson J.; Bjorheden R.; Hakkila P.; Lowe A. T.; Smith C. T. (eds) Bioenergy from sustainable forestry: guiding principles and practice. Kluwer, The Netherlands; 2002. Dordrecht 49-123.

Anterola A. M.; Lewis N. G. Trends in lignin modification: a comprehensive analysis of the effects of genetic manipulations/ mutations on lignification and vascular integrity. Phytochemistry 61: 221-294; 2002.

Benedict C.; Skinner J. S.; Meng R.; Chang Y.; Bhalerao R.; Huner N. P.; Finn C. E.; Chen T. H.; Hurry V. The CBF1-dependent low temperature signaling pathway, regulon and increase in freeze tolerance are conserved in Populus spp. Plant Cell Environ. 29: 1259-1272; 2006.

Boerjan W.; Ralph J.; Baucher M. Lignin biosynthesis. Ann. Rev. Plant Biol. 54: 519-546; 2003.

Burdon R. W.; Libby W. J. Genetically modified forests: from Stone age to modern biotechnology. Forest History Society, Durham, North Carolina, USA; 2006.

Busov V. B.; Meilan R.; Pearce, D. W.; Ma C.; Rood S. B.; Strauss S. $\mathrm{H}$. Activation tagging of a dominant gibberellin catabolism gene (GA 2-oxidase) from poplar that regulates tree stature. Plant Phys. 132: 1-9; 2003.

Chiang V. L.; Funaoka M. The difference between guaiacyl and guaiacyl-syringyl lignins in their responses to Kraft delignification. Holzforschung 44: 309-313; 1990.

Chichkova S.; Arellano J.; Vance C. P.; Hernandex G. Transgenic tobacco plants that overexpress alfalfa NADH-glutamate synthase have higher carbon and nitrogen content. J. Exp. Bot. 52: 2079-2084; 2001

Coleman H. D.; Samuels A. L.; Guy R. D.; Mansfield S. D. Perturbed lignification impacts tree growth in hybrid poplar-a function of sink strength, vascular integrity, and photosynthetic assimilation. Plant Phys. 148: 1229-1237; 2008.

Davis A. A.; Trettin C. C. Sycamore and sweetgum plantation productivity on former agricultural land in South Carolina. Biomass and Bioenergy. 30: 769-777; 2006. 
Dickmann D. L. Silviculture and biology of short rotation woody crops in temperate regions: then and now. Biomass Bioenergy. 30: 696-705; 2006

Dubouzet J. G.; Sakuma Y.; Ito Y.; Kasuga M.; Dubouzet E. G.; Miura S.; Seki M.; Shinozaki K.; Yamaguchi-Shinozaki K. OsDREB genes in rice, Oryza sativa L., encode transcription activators that function in drought-, high-salt- and cold-responsive gene expression. Plant J 33: 751-763; 2003.

Duguay J.; Jamal S.; Wang T. W.; Thompson J. E. Leaf-specific suppression of deoxyhypusine synthase in Arabidopsis thaliana enhances growth without negative pleiotropic effects. J. Plant Phys. 164: 408-420; 2007.

El-Khatib R.; Hamerlynck E. P.; Gallardo F.; Kirby E. G. Transgenic poplar characterized by ectopic expression of a pine cytosolic glutamine synthetase gene exhibits enhanced tolerance to water stress. Tree Phys. 24: 729-736; 2004.

English B. C.; De La Torre, Ugarte D. G.; Jensen K.; Hellwinckel C.; Menard J.; Wilson B.; Roberts R.; Walsh M. (2006) $25 \%$ Renewable energy for the United States by 2025: Agricultural and Economic Impacts. University of Tennessee Agricultural Economics, http://www. $25 \times 25$. org/storage/25x25/documents/ RANDandUT/UT-EXECsummary25X25FINALFF.pdf; 2006.

Frederick Jr. W. J.; Lien S. J.; Courchene C. E.; DeMartini N. A.; Ragauskas A. J.; Iisa K. Production of ethanol from carbhohydrates from loblolly pine: a technical and economic assessment. Bioresour Technol 99: 5051-5057; 2008.

Fu J.; Sampalo R.; Gallardo F.; Canavos F. M.; Kirby E. G. Assembly of a cytosolic pine glutamine synthetase holoenzyme in leaves of transgenic poplar leads to enhanced vegetative growth in young plants. Plant Cell Envir. 26: 411-418; 2003.

Goicoechea M.; Lacombe E.; Legay S.; Mihaljevic S.; Rech P.; Jauneau A.; Lapierre C.; Pollet B.; Verhaegen D.; Chaubet-Gigot N.; Grima-Pettenati J. EgMYB2, a new transcriptional activator from Eucalytpus xylem, regulates secondary cell wall formation and lignin biosynthesis. Plant J. 43: 553-567; 2005.

Gomez Jimenez M. D.; Canas Clemente L. A.; Madueno Albi F.; Beltran Porter J. P. Sequence regulating the anther-specific expression of a gene and its use in the production of androsterile plants and hybrid seeds. U.S. Patent No. 7078593; 2006.

Grabber J. H.; Ralph J.; Hatfield R. D.; Quideau S. p-hydroxyphenyl, guaiacyl, and syringyl lignins have similar inhibitory effects on cell wall degradation. J. Agric. Food Chem. 45: 2530-2532; 1997.

Good A. G.; Swarat A. K.; Muench D. G. Can less yield more? Is reducing nutrient input into the environment compatible with maintaining crop production? Trends Plant Sci. 9(597-6): 05; 2004.

Hsieh T. H.; Lee J. T.; Yang P. T.; Chiu L. H.; Charng Y. Y.; Wang Y. C.; Chan M. T. Heterologous expression of the Arabidopsis C-repeat/dehydration response element binding factor 1 gene confers elevated tolerance to chilling and oxidative stresses in transgenic tomato. Plant Physiol. 129: 1086-1094; 2002.

Hu J. J.; Tian Y. C.; Han Y. F.; Li L.; Zhang B. E. Field evaluation of insect resistant transgenic Populus nigra trees. Euphytica 121: 123-127; 2001.

Huntley S. K.; Ellis D.; Gilbert M.; Chapple C.; Mansfield S. D. Significant increases in pulping efficiency in $\mathrm{C} 4 \mathrm{H}-\mathrm{F} 5 \mathrm{H}-$ transformed poplars: improved chemical savings and reduced environmental toxins. J. Agric. Food Chem. 51: 6178-6183; 2003.

ISAAA. The International service for the acquisition of Agri-Biotech Applications (ISAAA) report, Global Status of Commercialized Biotech/GM Crops: 2008, http://www.isaaa.org; 2008.

Ito Y.; Katsura K.; Maruyama K.; Taji T.; Kobayashi M.; Seki M.; Shinozaki K.; Yamaguchi-Shinozaki K. Functional analysis of rice DREB1/CBF-type transcription factors involved in coldresponsive gene expression in transgenic rice. Plant Cell Phys. 47: 141-153; 2006

Jaglo-Ottosen K. R.; Gilmour S. J.; Zarka D. G.; Schabenberger O.; Thomashow M. F. Arabidopsis CBF1 overexpression induces COR genes and enhances freezing tolerance. Science 280: 104 $106 ; 1998$

Jaglo-Ottosen K. R.; Kleff S.; Amundsen K. L.; Zhang X.; Haake V.; Zhang J. Z.; Deits T.; Thomashow M. F. Components of the Arabidopsis C-repeat/dehydration-responsive element binding factor cold-response pathway are conserved in Brassica napus and other plant species. Plant Phys. 127: 910-917; 2001.

Just R. E., Alston J. M., Zilberman D. (eds.). Regulating Agricultural Biotechnology: Economics and Policy. Springer, New York; 2006.

Kasuga M.; Liu Q.; Miura S.; Yamaguchi-Shinozaki K.; Shinozaki K. Improving plant drought, salt, and freezing tolerance by gene transfer of a single stress-inducible transcription factor. Nature Biotech 17: 287-291; 1999.

Kasuga M.; Miura S.; Shinozaki K.; Yamaguchi-Shinozaki K. A combination of the Arabidopsis DREB1A gene and stressinducible rd29A promoter improved drought- and low-temperature stress tolerance in tobacco by gene transfer. Plant Cell Physiol. 45: 346-350; 2004.

Kobayashi F.; Takumi S.; Kume S.; Ishibashi M.; Ohno R.; Murai K.; Nakamura C. Regulation by Vrn-1/Fr-1 chromosomal intervals of $\mathrm{CBF}$-mediated Cor/Lea gene expression and freezing tolerance in common wheat. J Exp Bot. 56: 887$895 ; 2005$.

Leplé J.-C.; Dauwe R.; Morreel K.; Storme V.; Lapierre C.; Pollet B.; Naumann A.; Kang K.-Y.; Kim H.; Ruel K.; Lefèbvre A.; Joseleau J.-P.; Grima-Pettenati J.; De Rycke R.; AnderssonGunnerås S.; Erban A.; Fehrle I.; Petit-Conil M.; Kopka J.; Polle A.; Messens E.; Sundberg B.; Mansfield S. D.; Ralph J.; Pilate G.; Boerjan W. Down regulation of cinnamoyl-coenzyme A reductase in poplar: multiple-level phenotyping reveals effects on cell wall polymer metabolism and structure. Plant Cell 19: 3669$3691 ; 2007$.

Li X.; Jing-Ke Weng J.-K.; Chapple C. Improvement of biomass through lignin modification. Plant J. 54: 569-581; 2008.

Liu Q.; Kasuga M.; Sakuma Y.; Abe H.; Miura S.; YamaguchiShinozaki K.; Shinozaki K. Two transcription factors, DREB1 and DREB2, with an EREBP/AP2 DNA binding domain separate two cellular signal transduction pathways in drought- and lowtemperature-responsive gene expression, respectively, in Arabidopsis. Plant Cell 10: 1391-406; 1998.

Man Hui-min R.; Boriel R.; El-Khatib R.; Kirby E. G. Characterization of transgenic poplar with ectopic expression of pine cyotsolic glutamine synthetase under conditions of varying nitrogen availability. New Phytol (167): 31-39; 2005.

McKeand S.; Mullin T.; Byram T.; White T. Deployment of genetically improved loblolly and slash pine in the South. $J$. Forestry. 101(3): 32-37; 2003.

Mead D. J. Forests for energy and the role of planted trees. Crit. Rev. Plant sci 24: 407-421; 2005.

Mercker D. Short rotation woody crops for biofuels. University of Tennessee Agricultural Experiment Station. http://www. utextension.utk.edu/publications/spfiles/SP702-C.pdf; 2007

Mitsuda N.; Iwase, A.; Yamamoto H.; Yoshida, M.; Seki, M.; Shinozaki K.; Ohme-Takagi M. NAC transcription factors, NST1 and NST3, are key regulators of the formation of secondary walls in woody tissues of Arabiodopsis. Plant Cell 19: 270-280; 2007

Nasrallah M. E.; Nasrallah J. B.; Thorsness M. K. Isolated DNA elements that direct pistil-specific and anther-specific gene expression and methods of using same. United States Patent No. 5,859,328; 1999. 
Nathan R.; Katul G. G.; Horn H. S.; Thomas S. M.; Oren R.; Avissar R.; Pacala S. W.; Levin S. A. Mechanisms of long-distance dispersal of seeds by wind. Nature 418: 409-413; 2002.

Nehra N. S.; Becwar M. R.; Rottmann W. H.; Pearson L.; Chowdhury K.; Chang S.; Wilde H. D.; Kodrzycki R. J.; Zhang C.; Gause K. C.; Parks D. W.; Hinchee M. A. Forest biotechnology: innovative methods, emerging opportunities. In Vitro Cell. Dev. Biol. Plant. 41: 701-717; 2005.

Patzlaff A.; McInnis S.; Courtenay A.; Surman C.; Newman L. J.; Smith C.; Bevan M. W.; Mansfield S.; Whetten R. W.; Sederoff R. R.; Campbell M. M. Characterisation of a pine MYB that regulates lignification. Plant J. 46: 743-754; 2003.

Perlack R. D.; Turhollow W. L. L.; AF G. R. L.; Stokes B. J.; Erbach D. C. Biomass as a feedstock for a bioenergy and bioproducts industry: the technical feasibility of a billion-ton annual supply. US Department of Energy, Oak Ridge National Laboratory, Oak Ridge, TN; 2005.

Polle A.; Altman A.; Jiang X. Towards genetic engineering for drought tolerance in trees. In: Fladung M.; Ewald D. (eds) Tree transgenesis recent developments. Springer, Berlin; 2006.

Qin F.; Sakuma Y.; Li J.; Liu Q.; Li Y. Q.; Shinozaki K.; YamaguchiShinozaki K. Cloning and functional analysis of a novel DREB1/ $\mathrm{CBF}$ transcription factor involved in cold-responsive gene expression in Zea mays L. Plant Cell Phys. 45: 1042-1052; 2004.

Re D. B.; Rogers S. G.; Stone T. B.; Serdy F. S. Herbicide tolerant plants developed through biotechnology: regulatory considerations in the United States. In: Duke S. O. (ed) Herbicide resistant crops. CRC, New York, pp 341-347; 1996.

Rowell R. M. Handbook of Wood Chemistry and wood composites. Taylor \& Francis, a CRC Press Book. ISBN 0849315883, 9780849315886; 2005.

Sedjo R. A. Biotechnology in forestry: considering the costs and benefits. Resour. Future 145: 10-12; 2001.

Shani Z.; Dekel M.; Tsabary G.; Goren R.; Shoseyov O. Growth enhancement of transgenic poplar plants by over expression of Arabidopsis thaliana endo-1, 4- $\beta$-glucanase (cel1). Mol Breed 14: 321-330; 2004.

Short Rotation Forestry Handbook. University of Aberdeen. http:// www.abdn.ac.uk/wsrg/srfhbook; 1995.

Sims R. H. Short rotation coppice tree species selection for woody biomass production in New Zealand. Biomass Bioenergy 20: 329-335; 2001.

Sims R. H.; Venturi P. All year-round harvesting of short rotation coppice Eucalyptus compared with the delivered costs of biomass from more conventional short season, harvesting systems. Biomass Bioenergy 26: 27-37; 2004.

Stricker J. A.; Rockwood D. L.; Segrest S. A.; Alker G. R; Prine G. M.; Carter D. R. Short Rotation Woody Crops For Florida. University of Florida http://www.treepower.org/papers/strickerny. doc; 2000.

TimberMart-South Market News Quarterly 2008 13:1 pg. 28. http:// www.tmart-south.com/tmart/pdf/Qtr_01Q08news.pdf

Tuskan G.; DiFazio S.; Hellsten U.; Jansson S.; Rombauts S.; Putnam N.; Sterck L.; Bohlmann J.; Schein J.; Bhalerao R. R.; Bhalerao
R. P.; Blaudez D.; Boerjan W.; Brun A.; Brunner A.; Busov V.; Campbell M.; Carlson J.; Chalot M.; Chapman J.; Chen G.; Cooper D.; Coutinho P. M.; Couturier J.; Covert S.; Cunningham R.; Davis J.; Degroeve S.; dePamphilis C.; Detter J.; Dirks B.; Dubchak I.; Duplessis S.; Ehlting J.; Ellis B.; Gendler K.; Goodstein D.; Gribskov M.; Grigoriev I.; Groover A.; Gunter L.; Hamberger B.; Heinze B.; Helariutta Y.; Henrissat B.; Holligan D.; Islam-Faridi N.; Jones-Rhoades M.; Jorgensen R.; Joshi C.; Kangasjärvi J.; Karlsson J.; Kelleher C.; Kirkpatrick R.; Kirst M.; Kohler A.; Kalluri U.; Larimer F.; Leebens-Mack J.; Leplé J. C.; Déjardin A.; Pilate G.; Locascio P.; Lucas S.; Martin F.; Montanini B.; Napoli C.; Nelson D. R.; Nelson C. D.; Nieminen K. M.; Nilsson O.; Peter G.; Philippe R.; Poliakov A.; Ralph S.; Richardson P.; Rinaldi C.; Ritland K.; Rouzé P.; Ryaboy D.; Salamov A.; Schrader J.; Segerman B.; Sterky F.; Souza C.; Tsai C.; Unneberg P.; Wall K. The genome of black cottonwood, populus trichocarpa (Torr. \& Gray). Science 313(5793): 15961604; 2006.

Vagujfalvi A.; Aprile A.; Miller A.; Dubcovsky J.; Delugu G.; Galiba G.; Cattivelli L. The expression of several Cbf genes at the Fr-A2 locus is linked to frost resistance in wheat. Mol Genet. Genomics. 274: 506-514; 2005.

van Frankenhuyzen K.; Beardmore T. Current status and environmental impact of transgenic forest trees. Can. J. For. Res. 34: 1163 1180; 2004.

Vanholme R.; Morreel K.; Ralph J.; Boerjan W. Lignin engineering. Curr. Opinion Plant Biol. 11: 278-285; 2008.

Weng J.-K.; Li X.; Bonawitz N.; Chapple C. Emerging strategies of lignin engineering and degradation for cellulosic biofuel production. Curr. Opinion Biotech. 19: 166-172; 2008.

White R. H. Effect of lignin content and extractives on the higher heating value of wood. Wood Fiber Sci. 19: 446-452; 1987.

Williams C. G. Framing the issues on transgenic forests. Nat. Biotechnol 23: 530-532; 2005.

Williams C. G.; Davis B. Rate of transgene spread via long-distance seed dispersal in Pinus taeda. For Ecol Manag. 217: 95-102; 2005.

Yamaguchi-Shinozaki K.; Shinozaki K. Characterization of the expression of a desiccation-responsive rd29 gene of Arabidopsis thaliana and analysis of its promoter in transgenic plants. Mol. Gen. Genet. 236: 331-340; 1993.

Yamaguchi-Shinozaki K.; Shinozaki K. A novel cis-acting element in an Arabidopsis gene is involved in responsiveness to drought, low temperature, or high salt-stress. Plant Cell. 6: 251-264; 1994.

Yanofsky M. F. Methods of Suppressing Flowering in Transgenic Plants. United States Patent No. 6,987,214 B1; 2006.

Yi S. Y.; Kim J. H.; Joung Y. H.; Lee S.; Kim W. T.; Yu S. H.; Choi D. The pepper transcription factor CaPF1 confers pathogen and freezing tolerance in Arabidopsis. Plant Physiol. 136: 28622874; 2004.

Zhang X.; Fowler S. G.; Cheng H.; Lou Y.; Rhee S. Y.; Stockinger E. J.; Thomashow M. F. Freezing-sensitive tomato has a functional $\mathrm{CBF}$ cold response pathway, but a $\mathrm{CBF}$ regulon that differs from that of freezing-tolerant Arabidopsis. Plant J. 39: 905-919; 2004. 